\title{
Application of Computer Simulation in Innovation and Entrepreneurship Teaching Reform of Economics and Management Specialty
}

\author{
Li Liu, ${ }^{1}$ Cuifang Zhang $\mathbb{B D}^{2}$ and Tong $\mathrm{Wu}^{3}$ \\ ${ }^{1}$ School of Economics and Management, Wuchang Institute of Technology, Wuhan 430065, Hubei, China \\ ${ }^{2}$ School of Economics, Guangzhou College of Commerce, Guangzhou 511363, Guangdong, China \\ ${ }^{3}$ Business School, University of New South Wales, Kensington, NSW 2052, Australia \\ Correspondence should be addressed to Cuifang Zhang; z5381962@ad.unsw.edu.au
}

Received 13 September 2021; Revised 26 December 2021; Accepted 30 December 2021; Published 17 January 2022

Academic Editor: Punit Gupta

Copyright (C) $2022 \mathrm{Li} \mathrm{Liu} \mathrm{et} \mathrm{al.} \mathrm{This} \mathrm{is} \mathrm{an} \mathrm{open} \mathrm{access} \mathrm{article} \mathrm{distributed} \mathrm{under} \mathrm{the} \mathrm{Creative} \mathrm{Commons} \mathrm{Attribution} \mathrm{License,} \mathrm{which}$ permits unrestricted use, distribution, and reproduction in any medium, provided the original work is properly cited.

Innovation is the source and power of national development. Innovation and entrepreneurship education is the top priority of social construction and development and has become an important part of entrepreneurs. With the rapid development of economy, the society's demand for talents with innovation ability and practical ability is more urgent. Therefore, the teaching reform of blazing new trails and starting an undertaking for economics and management majors has become the top priority. The economics and management major should conform to the social era and the development of education and carry out blazing new trails and starting an undertaking teaching reform. On the foundation of broad research and analysis, according to the teaching situation of the economics and management major, this article carries out the blazing new trails and starting an undertaking teaching reform of the economics and management major. This study first puts forward the idea of blazing new trails and starting an undertaking education and computer simulation teaching model, then designs the educational method of blazing new trails and starting an undertaking education reform for college students, then constructs an entrepreneurial model for economics and management majors, and finally uses computer simulation technology to simulate it to understand the evaluation of various operating strategies of the teaching system. Through the questionnaire survey experiment, this study makes statistics on the current situation of students majoring in economics and management participating in blazing new trails and starting an undertaking activity and their views on the reform of blazing new trails and starting an undertaking education. For the experiment, first economics and management is understood, the experiment is designed, a digital model of the teaching process is constructed, a statistics of the experimental data is made, and the obtained data to verify the model are used. After collecting and analyzing the results of the questionnaire, the effective rate of the questionnaire was $97.4 \%$. Under the idea of blazing new trails and starting an undertaking education, the teaching reform of economics and management specialty in colleges should be carried out according to the situation of students in different grades and construct computer simulation experiment teaching through simulation technology, which is conducive to the innovative talent training.

\section{Introduction}

As the Belt and Road Initiatives grow with each passing day, the demand for professional talents in various industries continues to increase. This has brought new reform requirements for the personnel training in colleges. In the context of current social development, mass blazing new trails and starting an undertaking have become an unchangeable trend. As a discipline whose main work is to cultivate talents in economics and financial fields, the teaching innovation reform of economics and management specialty is also imminent [1]. In teaching, teaching reform is one of the effective ways to improve the learning ability and interest of college students, and it also guides the main direction of teachers' teaching. Therefore, it is necessary to speed up the research progress in the direction of economics 
teaching reform and management majors based on the idea of blazing new trails and starting an undertaking education, to provide the country and society with appropriate talents. Therefore, students majoring in economics and management can better help them understand professional courses through simulation experiments in computer and economics and management professional courses, rather than just accepting knowledge from textbooks. Furthermore, blazing new trails and starting an undertaking education can also find suitable methods for students according to some of their needs and provide them with special training and education, thereby improving their practical and social skills $[2]$.

\section{Literature Review}

Sievidova I A analyzed the basic mechanism of the formation of blazing new trails and starting an undertaking idea system and listed the factors that affect the teaching reform of economics and management in colleges and universities. This determines the importance and necessity of teaching reform to adapt to the concept of blazing new trails and starting an undertaking development. He summarized the problems existing in the transformation of teaching model, updating of teaching goals, and display of teaching results and integrated blazing new trails and starting an undertaking concept into the relevant directions of the reform of economics and management majors, but his research focuses too much on the theoretical aspects, which is not conducive to the substantial reform of the teaching direction [3]. Magnus et al. introduced the development of experimental teaching platform in the teaching system of economics and management. The platform is composed of a simulation teaching system, which is responsible for the parameterization of the regulator so that the system can operate effectively [4]. The main contribution of Srinivasa et al.'s research is to provide experimental verification for the digital model of the experimental teaching platform in the economics and management professional teaching system, to optimize the control design and parameterization. The real platform he provides helps to improve students' learning level, professional level, and practical ability. However, his project research cost is relatively high, which is not suitable for university development and use [5]. Gilbert studied educational programs with intergenerational influence. He found that the factors that lead to the development of children's achievement orientation are affected by the parents of the same period by studying the structural equation model based on 422 triples. However, this effect is also variable [6].

The innovation of this study lies in the following: in the process of research, the main problem is the innovative teaching of economics and management and the main concrete manifestation of the change in teaching methods. For this reason, (1) three reform experimental teaching schemes are designed, including case teaching, experiential teaching, and heuristic teaching; (2) the hierarchical teaching model is analyzed and established for different grades, different knowledge, and different abilities of economics and management majors; and (3) it is committed to exploring the reform of the experimental teaching model on economics and management under the computer simulation environment, the problems and shortcomings in the current experimental teaching model are analyzed, and the ideas in the reform of the teaching model of computer simulation experiments are put forward.

\section{Methods of Teaching Reform in Economics and Management Specialty Based on Innovation and Entrepreneurship}

3.1. Current Situation of Innovation and Entrepreneurship Education. As a scientific theory, the educational concept of blazing new trails and starting an undertaking economics and management also requires a complete set of scientific theoretical systems in line with its own characteristics $[7,8]$. Students can improve their comprehensive ability and prepare for entering society. However, China's blazing new trails and starting an undertaking education have just started, and its theoretical system is not mature. The root causes include the following two aspects [9]. On the one hand, the theoretical system of blazing new trails and starting an undertaking education lacks depth in content. At present, in the aspect of blazing new trails and starting an undertaking education, many domestic scholars focus on the analysis and discussion of the surface and related issues of blazing new trails and starting an undertaking education, but not the substantive and fundamental issues such as the goal, practice system, and evaluation system of blazing new trails and starting an undertaking education. On the other hand, the teaching method of the current innovation and starting an undertaking theory system is relatively single, and it is difficult to apply it to normal teaching [10]. In fact, most of the domestic research on blazing new trails and starting an undertaking education theory in China stays in theoretical research, and few scholars use practical methods for research, and empirical research is even less [11]. This situation restricts the rapid development of theoretical research. In this social environment, schools can introduce theoretical teaching methods and gradually realize teaching innovation [12]. In addition, combined with some advanced foreign experience and technology, it has laid a good foundation for China's modernization theory [13].

Judging from the current situation, my country's economic system is not perfect, and an economic system suitable for domestic social development has not yet been formed $[14,15]$. Judging from the current situation, if you want to develop blazing new trails and starting an undertaking education, higher education institutions should investigate and screen the current socioeconomic contradictions and problems, find out the root causes of the problems, and find solutions to these contradictions after careful analysis $[16,17]$. On the other hand, institutions must accurately analyze and grasp the development of the market economy on the basis of in-depth analysis of the market, understand the law of market development, and promote the achievements of market system innovation and 
technological innovation $[3,18]$. Institutions should explore the combination of social and market needs, education, and scientific research and closely integrate with blazing new trails and starting an undertaking education $[19,20]$.

\subsection{Insufficiency and Problems of Innovation and Entrepreneurship Education Teaching Reform}

3.2.1. Blazing New Trails and Starting an Undertaking Education Model Have Not Yet Been Formed. In some colleges, leaders do not pay much attention to blazing new trails and starting an undertaking education, and the relevant courses set by the school are less, so it is difficult to form a certain atmosphere of blazing new trails and starting an undertaking education; for students, they may be more prepared for the national civil servant examination or postgraduate entrance examination or directly participate in work. These may make the blazing new trails and starting an undertaking education model of some universities difficult to form [21].

3.2.2. Few Courses. Many colleges and universities lack systematic, comprehensive, and detailed blazing new trails and starting an undertaking education course, and most of them stay in theoretical teaching and lack practical operation. Students only understand textbook knowledge and theory, but do not learn how to put textbook knowledge into practice. In addition, there are some problems such as the lack of clear positioning and training objectives in some colleges and universities [22].

3.2.3. Lack of Experienced Teachers. Teachers in some local colleges and universities usually work mainly on teaching, and they invest less energy and time in scientific research. As we know, very few teachers have rich experience and innovative ability. It is necessary to restrict blazing new trails and starting an undertaking teacher to the students' blazing new trails and starting an undertaking guidance experience.

3.2.4. Lack of Practical Platform. Blazing new trails and starting an undertaking education need the support of human, material, and financial resources. Not only should there be an experimental base on campus, but also there should be a corresponding practice base outside the school. However, no university can withstand this pressure for the establishment of entrepreneurship parks and entrepreneurial bases. What is more, even the entrepreneurship experimental base on campus cannot provide students with it.

\subsection{Methods of Teaching Reform of Economics and Management Majors}

3.3.1. Literature Retrieval. Through famous paper websites such as CNKI, a large number of documents are retrieved, classified, summarized, and analyzed. The development situation, knowledge demand, and training model of economics and management major teaching reform under the concept of economics and management teaching reform in recent years are consulted, and the training programs of excellent colleges and universities are carefully studied; then, it analyzes the innovation of foreign literature. This article reviews the historical evolution and current situation of the educational reform of economics and management and uses relevant experience to provide a research foundation and theoretical basis. Research on education reform in economics and business management is based on the idea of blazing new trails and starting an undertaking education.

3.3.2. Text Analysis. This method is expected to select six well-known universities in North China, East China, West China, and Central China and conduct a text analysis of the reform and training programs of the economics and management majors of these six universities, to understand and learn from the relevant experience of excellent colleges on the teaching innovation reform of economics and management majors under the idea of blazing new trails and starting an undertaking education.

3.3.3. Questionnaire Survey. The article selects 6 well-known colleges and universities participating in this research to receive blazing new trails and starting an undertaking education and the college's own teachers as the questionnaire survey objects. Through the questionnaire survey of teachers and students, the reform and cultivation of blazing new trails and starting an undertaking education in economics and management majors are understood, and statistical analysis on unreasonable suggestions in the training process and problems in the teaching practice is conducted.

\subsection{Teaching Reform Experiment of Economics and Management Majors}

3.4.1. Economics and Management Teaching Reform Design. China's higher education is basically a unified teaching model, a single teaching plan, and so on, almost ignoring the personality of students. Among them, the blazing new trails and starting an undertaking education mainly adopt the single indoctrination method and tend to teach and assess the theoretical knowledge. If we want to make the blazing new trails and starting an undertaking education of economics and management students to achieve effective results, we must reform the single teaching method in the classroom, adopt a variety of methods, and create a new teaching atmosphere. The blazing new trails and starting an undertaking teaching design process are shown in Figure 1.

The purpose of this research tends to teach and evaluate theoretical knowledge, so that the blazing new trails and starting an undertaking education of economics and management students can achieve practical results.

(1) Case Teaching Design. Case teaching design is through one or several unique and representative blazing new trails and starting an undertaking practice typical case as the teaching content, using vivid forms to give people the feeling 


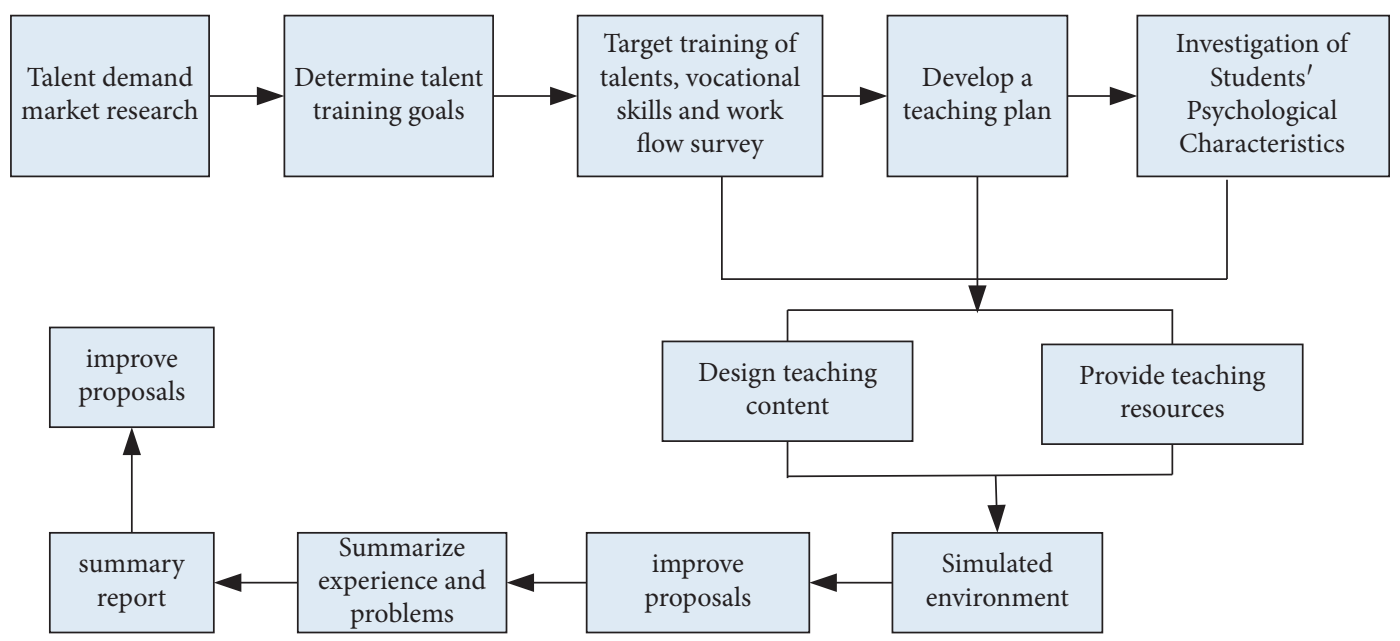

FIGURE 1: Innovative entrepreneurship teaching design flowchart.

of being in the scene, and it is convenient for students to understand and study the course. Instead of talking to themselves in class, teachers need to learn how to organize teaching by citing cases, master the progress of the course and guide the direction of discussion, and discuss problems with students. Students can increase their knowledge by understanding and being familiar with other people's entrepreneurial experience, show real examples to students, and analyze market economy laws using cases, to realize the development of ideas and stimulate students' interest in blazing new trails and starting an undertaking.

(2) Experiential Teaching. The purpose of experiential teaching is to cultivate students' self-improvement, selfreliance, innovation, and other qualities and stimulate students' love of learning, and it is possible to stimulate their personal teaching method. In the teaching process, we should mobilize students' learning enthusiasm, make the learning of double innovation education become the subjective things that students want to do, integrate the cognitive process of students with the emotional experience process, and let students learn the relevant knowledge in the experiential teaching. The core of experiential teaching design is to stimulate students' emotion and interest. It is a teacher-led and student-centered teaching model. Teachers design a mode of experience to guide students out of the complex environment and uncertain risks, and this can increase students' interest in innovation, entrepreneurship, and innovative thinking, thereby cultivating their creative thinking.

(3) Heuristic Teaching Design. The advantage of heuristic education is that it can guide students to acquire knowledge according to various methods of teachers. Then, teachers provide hypothesis of problems based on the actual situation of students, take inspiring students' thinking as the core, to mobilize students' learning enthusiasm, inspire students to think independently, find problems, and finally solve practical problems, to cultivate college students' practical ability of analysis, decision-making, operation, and management. Some educators have said that "the most effective learning method is to let students learn in the process of experience and creation, which is more obvious than the cramming teaching method. Without pressure, students can learn happily in the experience atmosphere, enable students to gradually develop the habit of serious study."

3.4.2. Interview Design. The whole process of investigation can be composed of two aspects: the first part is the basic information of the interviewee and the second part is the content of the questionnaire. This article aims to analyze the overall status quo of blazing new trails and starting an undertaking education in domestic colleges and the atmosphere of economics and management education including the statistics of the collected data and the integration of the current situation of education. Then, where the problem lies is found out, an in-depth analysis of it is conducted, and finally detailed measures for reform are obtained.

(1) Subject of Investigation. The survey objects of this questionnaire are the students who accept blazing new trails and starting an undertaking education in six famous colleges and universities in the North, East, West, and Central China, as well as the blazing new trails and starting an undertaking teacher set up by the colleges. The selected teachers are senior teachers of the college and have a long teaching experience. They have a deep understanding of the development of blazing new trails and starting an undertaking education in the college and have personally participated in the formulation of education reform plan for economics and management majors; the students selected in the questionnaire survey are students of economics and management major, covering all grades.

(2) Questionnaire Survey Content. For teachers, the questionnaire content includes age, professional title, education background, subject background, management department, full-time and part-time teachers, teaching or work category, whether they have relevant qualification certification, 
whether they have enterprise management experience or entrepreneurial experience, whether they have presided over or participated in research on blazing new trails and starting an undertaking, working hours, and the largest number of teachers in the education process. For students, the questionnaire includes gender, age, grade, whether they have participated in blazing new trails and starting an undertaking association, whether they have participated in blazing new trails and starting an undertaking competition, do they have work experience, working hours, and whether they are interested in entrepreneurship.

(3) Questionnaire Survey Statistics. The SO JUMP matches with the conventional questionnaire investigation, and it has the assets of precise data, high confidence level, simplicity of manipulation, and perfect statistical function, and therefore, it has been broadly used in university study. This investigation adopted the method of online random sampling. 100 questionnaires were issued to teachers, 100 were returned, and the effective rate was $100 \%$; 500 questionnaires were issued to students, and 487 were returned, and the effective rate was $97.4 \%$. The sample size of the questionnaire survey was 100 questionnaires for teachers and 500 questionnaires for students. 87 valid questionnaires were obtained for teachers and 412 for students. The questionnaire is distributed randomly.

3.4.3. Computer Simulation Teaching. The teaching of economics and management is more theoretical and lacks reasonable practical teaching. For this reason, this study proposes computer simulation teaching. The preparation of the computer simulation teaching system mainly includes the collection of pictures, audio and video materials, and the design of the network teaching platform. The teaching center has carried out this design and experiment in previous teaching activities and has certain experience. The teachers should be communicated before simulation teaching, and preparations for simulation teaching are made. IEE generally refers to the British Institute of Engineering and Technology.

The teachers of the teaching group prepared lessons collectively, visited and inspected the site, communicated and cooperated with each other, and discussed the whole process of the teaching design. The layout design of the simulated teaching scene, the teaching content, and the preparations that students should make are discussed. Particular attention should be paid to communicating with teachers and discussing the use and cooperation of multimedia, computer, and simulation teaching.

(1) The simulation of corporate competition conforms to the learning theory of constructivism. To make good decisions, students have to consider many factors. There is no simple formula to follow. Students put themselves in a simulated situation to think, analyze the external environment and internal factors of the enterprise, communicate, exchange, argue, and negotiate with their peers, and seek satisfactory decision-making plans. A good enterprise competition simulation software should leave enough room for imagination and a stage for students to display their decision-making ability, so that students can develop their inherent potential under the strong encouragement of competition.

(2) Economics and management students and business managers have a strong interest in this teaching and training method. Competitiveness, interest, and practicality of competitive simulation are unmatched by other classroom teaching methods. We admit that case teaching is an effective teaching method for many years. Compared with case teaching, competition simulation is more antagonistic, the application of knowledge is more comprehensive, and the students' enthusiasm appears higher.

\subsection{Teaching Reform of Economics and Management Majors}

3.5.1. Survey of Teachers. According to the results of the questionnaire survey, the content of the questionnaire survey is mainly focused on the survey of relevant information such as age, academic qualifications, and teaching subjects. The basic situation of teachers is obtained and drawn into a table, as shown in Table 1 ,

The analysis of blazing new trails and starting an undertaking is mainly based on the statistics of the survey process of entrepreneurial experience in the survey process in Table 1. According to Table 1, the proportion of teachers with master's degree is $62 \%$, the percentage of doctoral degree is $26 \%$, and that of bachelor's degree is $12 \%$. This shows that most innovative and entrepreneurial teachers in most famous universities have high education, which can better guide students to conduct blazing new trails and starting an undertaking activity using knowledge and experience; from the perspective of teaching sector, 59\% of teachers lead the study. Students carry out practical activities, which can make students experience blazing new trails and starting an undertaking more quickly; the disadvantage is that, from the perspective of the working years of teachers, most teachers have less years of education, and the experience may be relatively insufficient.

3.5.2. Survey of the Students Majoring in Economics and Management. Through the analysis of the data in the figure, the cognition and willingness of students of different grades in these colleges and universities can be obtained and drawn, as shown in Table 2.

According to the analysis in Table 2, it can be concluded that the economic and management students who have participated in the entrepreneurship and innovation association are more inclined to start a business, while the economic and management students who have not participated in the entrepreneurship and innovation association do not want to start a business; in addition, the number of students who participated in the entrepreneurship and innovation competition was significantly less than the number of students who did not participate. To better observe and compare, the table is drawn into a graph, and we see Figure 2. 
TABLE 1: Basic situation of teachers.

\begin{tabular}{|c|c|c|c|}
\hline \multicolumn{2}{|c|}{ Statistical items } & \multirow{2}{*}{$\begin{array}{c}\text { Number } \\
11\end{array}$} & \multirow{2}{*}{$\begin{array}{c}\text { Percentage }(\%) \\
11\end{array}$} \\
\hline \multirow{4}{*}{ Age } & 30 and under & & \\
\hline & 31 to 40 & 52 & 52 \\
\hline & 41 to 50 & 34 & 34 \\
\hline & 51 to 60 & 3 & 3 \\
\hline \multirow{3}{*}{ Educational background } & Doctor & 26 & 26 \\
\hline & Master & 62 & 62 \\
\hline & Bachelor & 12 & 12 \\
\hline \multirow{3}{*}{ Teaching section } & Theory teaching & 41 & 41 \\
\hline & Practical teaching & 22 & 22 \\
\hline & Theory + practice & 37 & 37 \\
\hline \multirow{2}{*}{ Entrepreneurial experience } & Yes & 24 & 24 \\
\hline & No & 76 & 76 \\
\hline \multirow{2}{*}{ Project research } & Yes & 44 & 44 \\
\hline & No & 56 & 56 \\
\hline \multirow[b]{2}{*}{ Working years } & 1 to 5 & 68 & 68 \\
\hline & 6 to 10 & 16 & 16 \\
\hline \multirow[b]{2}{*}{11} & 11 to 15 & 11 & 11 \\
\hline & 15 and above & 5 & 5 \\
\hline
\end{tabular}

TABLE 2: Basic information of students majoring in economics and management.

\begin{tabular}{lcc}
\hline Statistical items & Number of students & Percentage (\%) \\
\hline Join the club & 284 & 56.8 \\
Have not participated in the club & 216 & 43.2 \\
Participated in the competition & 167 & 33.4 \\
Have not participated in the competition & 333 & 66.6 \\
Want to start a business & 259 & 51.8 \\
Not want to start a business & 241 & 48.2 \\
\hline
\end{tabular}

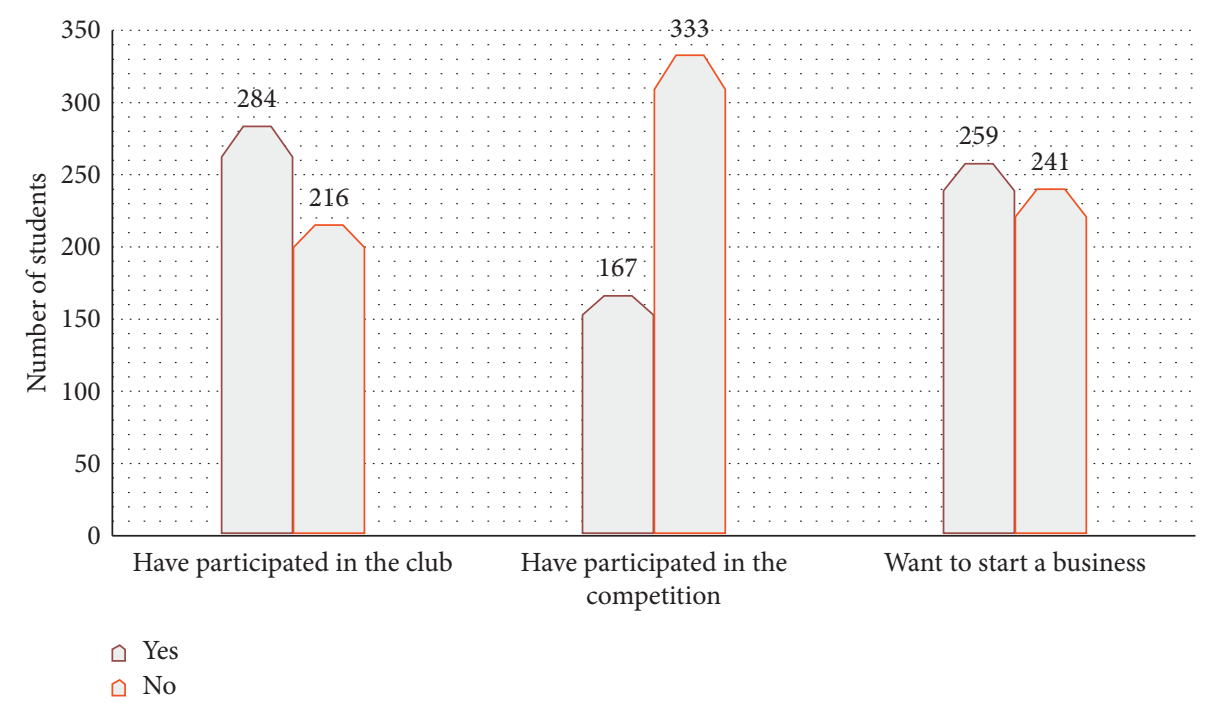

FIGURE 2: Basic information of students majoring in economics and management.

According to Figure 2, the biggest gap among the selected economics and management majors is whether they have joined the double creation competition, with a total difference of 166, The problems of blazing new trails and starting an undertaking education in colleges and universities can be inferred that the lack of experimental bases and less practical activities lead to the gap. To promote students' performance and practice of activities, colleges and universities proposed to accelerate the reform of economics and management disciplines. 


\subsubsection{Teaching Model of Economics and Management Majors} under the Idea of Blazing New Trails and Starting an Undertaking Education. In the process of the questionnaire survey, the statistical data show that they are not similar in the past experience of different grades of college students majoring in economics and management. The specific differences reveal in Figure 3.

In addition, during the questionnaire survey, the support rate of different grades of students majoring in economics and management for the teaching reform of the professional courses under the concept of blazing new trails and starting an undertaking was statistically analyzed, as shown in Figure 4.

Under the idea of blazing new trails and starting an undertaking education, the purpose of teaching economics and management is to cultivate applied talents with innovative thinking and entrepreneurial abilities. It is especially important to establish a training model based on different levels, different abilities, and different knowledge to carry out the teaching of the right medicine to the case.

(1) Teaching and Training of Economics and Management Majors under the Idea of Blazing New Trails and Starting an Undertaking Education for Freshmen. Generally speaking, college freshmen have not been exposed to the idea of blazing new trails and starting an undertaking education and have little knowledge of blazing new trails and starting an undertaking education. Colleges and universities must offer blazing new trails and starting an undertaking education courses, such as learning college students' blazing new trails and starting an undertaking education, college students' career planning, and entrepreneurship management. Universities should actively carry out various forms of blazing new trails and starting an undertaking knowledge lectures, or introduce some outstanding companies to students for internships, to understand the development process of these enterprises and encourage freshmen's innovative thinking and entrepreneurial consciousness. In addition, colleges and universities should organize a variety of community activities, so that students with strong ability in blazing new trails and starting an undertaking can drive the relatively weak students forward. Only in this way can freshmen at different levels promote each other. In addition, through the campus broadcast, campus newspaper, campus network, and other campus culture publicity, the blazing new trails and starting an undertaking spirit are rooted in the students' hearts, to achieve the purpose of encouraging students' learning progress.

(2) Blazing New Trails and Starting an Undertaking Education for Sophomores. Although sophomores have formed the awareness of blazing new trails and starting an undertaking, they still do not know the specific implementation methods. Therefore, it is very important to improve their thinking and innovation ability. Therefore, through the guidance of some experienced teachers, a series of innovative and entrepreneurial projects can be established to improve the students' personal qualities and the collective sense of honor of the class. For students with a highly innovative and

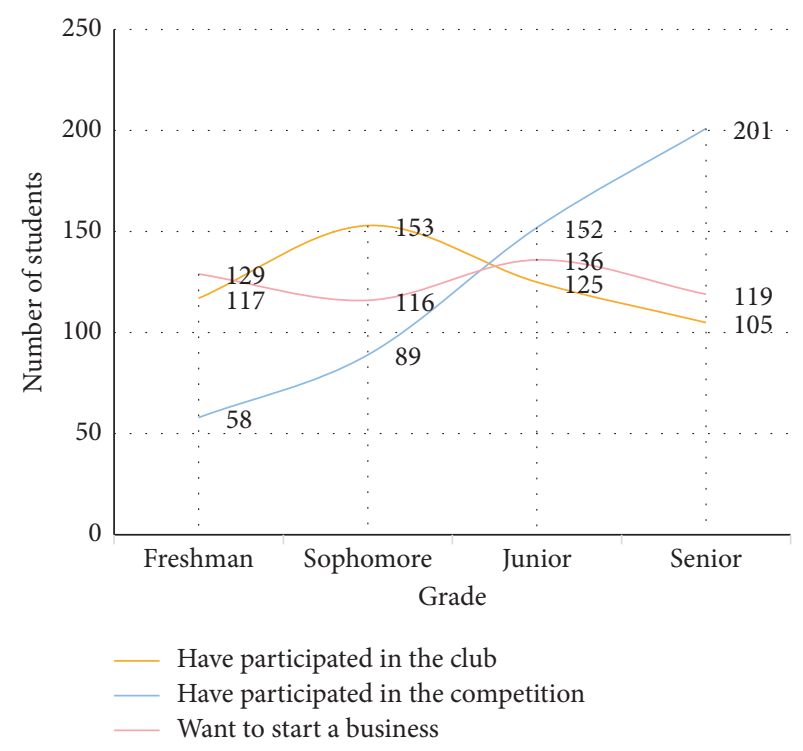

FIGURE 3: Blazing new trails and starting an undertaking experience of students of different grades.

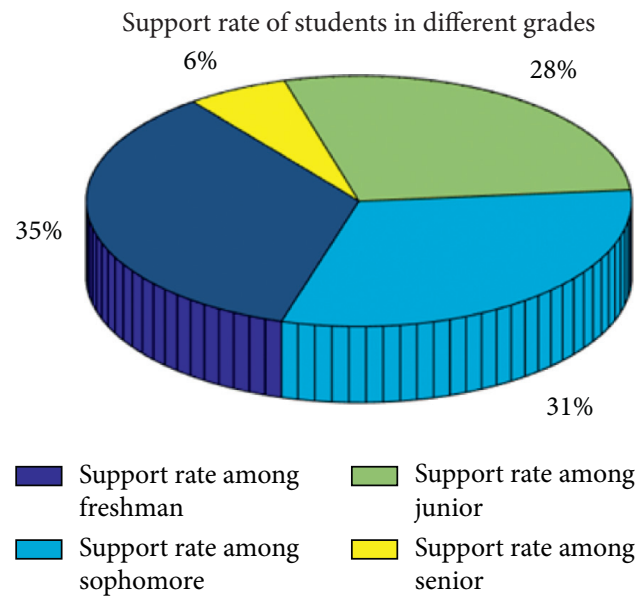

Figure 4: Support rate of students in different grades.

entrepreneurial spirit, students are guided to complete experimental projects independently, and research papers based on experimental results are published, which are combined in various magazines. In addition, universities must also encourage students to create and invent. When formulating a training plan for entrepreneurial spirit, it is necessary to formulate an appropriate training plan according to the personality of various students. At the same time, the theory of blazing new trails and starting an undertaking must be strengthened. The school also needs to actively organize students to participate in internships in experimental bases and affiliated companies inside and outside the school to improve students' practical ability and innovation and entrepreneurial ability. Moreover, universities need to combine blazing new trails and starting an undertaking education with community activities and improve students' innovative thinking and entrepreneurial ability. To mobilize enthusiasm, the association should 
organize various training activities and competitions to improve their blazing new trails and starting an undertaking capability.

The economics and management course takes blazing new trails and starting an undertaking education as the goal and as the main purpose to create a strong entrepreneurial cultural atmosphere in the university. Through the enlightenment of entrepreneurial content, we feel that we can continuously improve and cultivate good business behavior habits in the training, departments, and activities provided in various fields of the school. Conclusions inspired by entrepreneurship, we can provide training for school students and let students establish a good corporate awareness. Let students broaden their vision of connecting with business leaders through campus activities and establish a systematic training system.

\section{Conclusions}

This study analyzes the education status of some universities and the basic situation of blazing new trails and starting an undertaking students majoring in economics and business through student statistics and various guidance methods such as design case education and experience education. Humanized education provides some new ideas for studying economics and business education reform based on the idea of blazing new trails and starting an undertaking education.

Then, we use computer simulation and simulation experiments to teach economics and management courses, which are closely combined with the learning concept of "discoveryoriented learning and research-oriented learning," providing students with valuable educational resources. An experimental and step-by-step education model is created within students to effectively cultivate students' innovative practical ability. The computer simulation teaching experiment mentioned in the article is mainly a simulation of the current concept, not a real experiment. Computer simulation teaching experiment has built a new experimental education model adapted to the information age and created a step-by-step internal experimental teaching method for basic learning, which can effectively cultivate students' practical and innovative abilities. Under the idea of blazing new trails and starting an undertaking education, the teaching reform of economics and management majors in colleges and universities should be carried out according to the conditions of students of different grades. The use of simulation technology to construct computer simulation experiment teaching is conducive to the cultivation of innovative talents.

Through the investigation and analysis of the basic situation of all levels of students majoring in economics and management in colleges, it is transformed into establishing a hierarchical training model based on different grades, different knowledge, and different abilities. In addition, professional training plans for various abilities have been developed. If it is a senior student, it is necessary to develop a project plan. To provide financial support, track and guide projects, and help superior experts to innovate and entrepreneurs to develop economy and management, we will recommend related projects to superiors.

\section{Data Availability}

The data that support the findings of this study are available from the corresponding author upon reasonable request.

\section{Disclosure}

The authors received no financial support for the research, authorship, or publication of this article.

\section{Conflicts of Interest}

The authors declare that they have no conflicts of interest.

\section{References}

[1] T. S. Kishore and M. Sanapala, "Towards self-reliant renewable power generation: techno-economic analysis of an educational institute based hybrid power system," Water and Energy International, vol. 61, no. 7, pp. 31-37, 2018.

[2] M. Judge, "Large-scale laboratory teaching for first-year EEE undergraduates," International Journal of Electrical Engineering Education, vol. 55, no. 1, p. 88, 2018.

[3] I. A. Sievidova, "Factors affecting the economic management efficiency of agricultural enterprises in Ukraine," Problems and Perspectives in Management, vol. 15, no. 2, pp. 203-210, 2017.

[4] D. Magnus, L. Carbonera, L. Pfitscher, D. Bernardon, A. Tavares, and C. Scharlau, "Experimental and educational platform for operation tests and parameterization of power system regulators and stabilizers," IEEE Latin America Transactions, vol. 17, no. 01, pp. 54-62, 2019.

[5] K. G. Srinivasa K G, B. J. Sowmya Bj, A. Shikhar, R. Utkarsha, and A. Singh, "Data analytics assisted internet of things towards building intelligent healthcare monitoring systems," Journal of Organizational and End User Computing, vol. 30, no. 4, pp. 83-103, 2018.

[6] C. Gilbert, "Creating educational destruction: a critical exploration of central neoliberal concepts and their transformative effects on public education," The Educational Forum, vol. 83, no. 1, pp. 60-74, 2018.

[7] W. Wu, Y. Liu, C. H. Wu, and S. B. Tsai, "An empirical study on government direct environmental regulation and heterogeneous innovation investment," Journal of Cleaner Production, vol. 254, Article ID 120079, 2020.

[8] A. Schmitz, D. Urbano, M. Guerrero, and G. A. Dandolini, "Activities related to innovation and entrepreneurship in the academic setting: a literature review," Innovation, Technology, and Knowledge Management, vol. 13, no. 2, pp. 1-17, 2016.

[9] M. A. Cusumano, "The puzzle of Japanese innovation and entrepreneurship," Communications of the ACM, vol. 59, no. 10, pp. 18-20, 2016.

[10] G. Sharma, "Innovation and entrepreneurship research in India from 2000 to 2018: a bibliometric survey," The Journal of Management Development, vol. 38, no. 4, pp. 250-272, 2019.

[11] S. Sysoieva and O. Protsenko, "Implementation of the continuing education concept in the european educational area: regulatory provision," Continuing Professional Education: Theory Into Practice, no. 2, pp. 78-84, 2020.

[12] J. Petrovic, "The influence of Dewey's educational concept on Serbian pedagogues in defining education," Godisnjak Pedagoskog fakulteta u Vranju, no. 7, pp. 153-168, 2016.

[13] O. M. Herasymenko, "Risk identification as a tool for economic security for risk-oriented approach to business 
management," Cherkasy University Bulletin: Economics Sciences, vol. 2018, no. 4, pp. 22-33, 2018.

[14] M. Hamid, A. Mohsen, and A. Reza, "Reconfigurable rapid prototyping platform for power electronic circuits and systems for research and educational purposes," IET Power Electronics, vol. 11, no. 7, pp. 1314-1320, 2018.

[15] J. T. Mortimer, L. Zhang, C.-Y. Wu, J. Hussemann, and M. K. Johnson, "Familial transmission of educational plans and the academic self-concept," Social Psychology Quarterly, vol. 80, no. 1, pp. 85-107, 2017.

[16] J. Mutale, "Educational challenges: issues with power engineering education [in my view]," IEEE Power and Energy Magazine, vol. 16, no. 5, pp. 120-117, 2018.

[17] I. S. Leushina, A. A. Temerbekova, and A. A. Temerbekova, "Analysis of the main approaches to definition of the concept universal educational actions»»," Tomsk State Pedagogical University Bulletin, vol. 1, no. 1, pp. 28-32, 2017.

[18] M. Zhou, Y. Wang, Y. Liu, and Z. Tian, "An information-theoretic view of WLAN localization error bound in GPS-denied environment," IEEE Transactions on Vehicular Technology, vol. 68, no. 4, pp. 4089-4093, 2019.

[19] S. Fedulova, V. Dubnytskyi, V. Komirna, and N. Naumenko, "Economic development management in a water-capacious economy," Problems and Perspectives in Management, vol. 17, no. 3, pp. 259-270, 2019.

[20] T. V. Morozova, T. Polyanskaya, and V. E. Zasenko, "Economic analysis in the financial management system," International Journal of Applied Business and Economic Research, vol. 15, no. 23, pp. 117-124, 2017.

[21] P. Partlova, J. Strakova, J. Vachal, F. Pollak, and J. Dobrovic, "Management of innovation of the economic potential of the rural enterprises," Marketing and Management of Innovations, no. 2, pp. 340-353, 2020.

[22] C. Xiang and L. Dehua, "Exploration on projectized-teaching reform of "crushing and grinding technology" in higher vocational education," World Nonferrous Metals, vol. 000, no. 19, pp. 224-226, 2018. 